\title{
Dominant Species of Polychaetous Annelids of Georges Bank
}

\author{
D. Maurer and W. Leathem
}

University of Delaware, College of Marine Studies, Lewes, Delaware 19958, USA

\begin{abstract}
During the course of a study of polychaetous annelids of Georges Bank, USA, 333 taxa of polychaetes (winter, 263; spring, 264) belonging to 46 families (winter, 30; spring, 33) were identified. The top taxa in terms of abundance accounted for a mean of $88 \%$ (winter) and $89.3 \%$ (spring) of the number of polychaetes per station. Based on density and frequency of occurrence, the top taxa for winter were Spiophanes bombyx, Exogone hebes, Euclymene collaris, Exogone verugera, Arcidea catherinae, Phyllodoce mucosa, Cirratulidae spp., Parapionosyllis longicirrata, Schistomeringos caeca, Spiophanes kroyeri, Sphaerosyllis erinaceus, Tharyx sp. B, Goniadella gracilis, Sabellidae spp., and Jasmineira filiformis. In the spring, Chone infundibuliformis, Maldanidae spp., Nephtyidae spp., Notomastus latericeus, and Euchone incolor were among the top taxa which included 10 taxa from the winter. Ten species were selected and quantitatively examined for their distribution and ecological relationships with environmental variables. These dominant species are an important component of macrobenthic infauna from Georges Bank to Chesapeake Bay. Approximately 15 families of polychaetes are important taxa for the continental shelves ranging from California to Alaska and Chesapeake Bay to Georges Bank.
\end{abstract}

\section{INTRODUCTION}

During an earlier account, the general ecological distribution of polychaetous annelids of Georges Bank was reported (Maurer and Leathem, 1980). Since that account was primarily concerned with the relationship between general biotic factors (number of species, density, biomass, diversity, and dominance) and a whole host of abiotic factors (temperature, salinity, sediment size, etc.), individual species were not emphasized. The purpose of this account is to present data on the relationship between dominant (density and frequency of occurrence) taxa and environmental factors.

In the earlier account it was reported that polychaetes comprised a mean of $53.8 \%$ of the number of all infaunal species, $53 \%$ of the density of all infauna, and $60.5 \%$ of the wet weight biomass of all soft-bodied infauna (Maurer and Leathem, 1980). Mean number of species and density per station were higher in the spring than in the winter. Mean number of species increased with depth, temperature, and percent gravel and decreased with dissolved oxygen. Mean density decreased with fine grained sediment and increased with gravel and with depth in the winter. In the spring, mean biomass increased with dissolved oxygen and decreased with lower temperature. Some of these rela- tionships were independently confirmed through principal component analyses, which indicated that percent gravel and depth were very important factors influencing the ecology of Georges Bank polychaetes. Based on cluster analysis 8 site groups emerged, which after reallocation of a few stations, was reduced to 5 site groups. These groups included Nantucket Shoals and the greater part of Georges Bank, southern slope, southeastern shelf, northern slope, and the Gulf of Maine. Nantucket Shoals and the Great South Channel area contained high densities and biomass.

Considerable research on benthic invertebrates including polychaetes has been conducted in the New England area for a long time (Pratt, 1973; TRIGOMPARC, 1974; Wigley and Theroux, 1976). The most comprehensive treatment of polychaetes from the northeast Atlantic coast of the United States was presented by Pettibone (1963a). Since then she has published on a large number of families, some of which are relevant to Georges Bank (Pettibone, 1962, 1963b, 1965, 1966, 1969, 1970a, b, 1971, 1975, 1976, 1977). Deep-water polychaetes from the western Atlantic were described by Hartman (1965) and Hartman and Fauchald (1971). Studies of the biology and ecology of polychaetes from the New England area include: Spio setosa, Nephtys incisa, Cistena gouldii, C. hyperborea, Ampharete acutifrons, Polydora spp., 


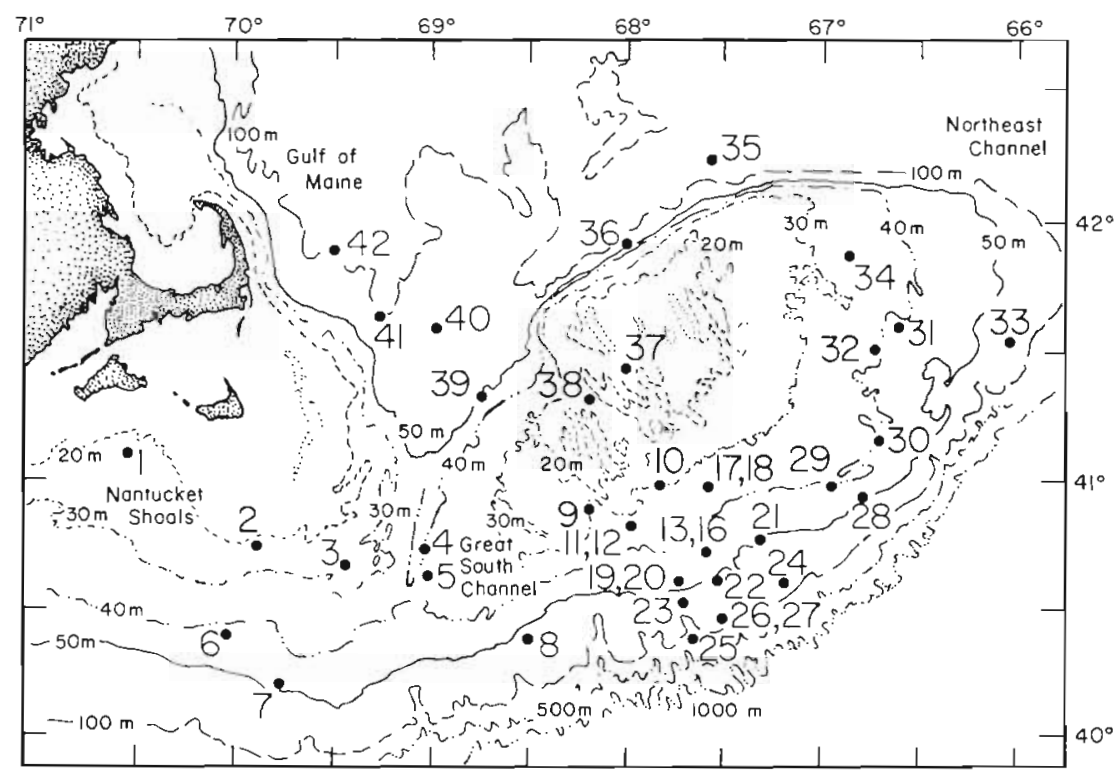

Fig. 1. Location map of benthic stations from Georges Bank

Clymenella torquata, C. zonalis, Glycera dibranchiata, G. capitata, Nereis virens, and Streblospio benedicti (Sanders, 1956; Mangum, 1964; Dean, 1965; Richards and Riley, 1967; Simon, 1967; Blake, 1969; Peer, 1970; Creaser, 1973; Dean 1978a, b). Other sources of taxonomic literature which were useful in our studies were Fauvel (1923, 1927), Day (1967a, b, 1973), Blake (1971), Foster (1971), Hartmann-Schröder (1971), Banse and Hobson (1974), Gardner (1975) and Fauchald (1977). Kinner and Maurer (1978) described a total of 136 species representing 34 families from the Delaware Bay region. Kinner (1978) identified and analyzed a series of quantitative samples from the continental shelf ranging from Cape Cod to Cape Hatteras. A large species list of polychaetes off New Jersey was presented by Boesch et al. (1976).

\section{MATERIALS AND METHODS}

Station. latitudes and longitudes for Georges Bank sediment samples together with a detailed account of materials and methods are presented in Maurer and Leathem (1980). During 1977, 408 quantitative sediment samples were taken in winter (238) and spring (170) with a modified Smith-McIntyre grab $\left(0.1 \mathrm{~m}^{2}\right)$ from Georges Bank off New England (Fig. 1).

\section{Field}

Procedures for removal of sediment samples and laboratory analyses of supporting data used in this account are presented in the draft final report for the
New England Outer Continental Shelf Environmental Benchmark, 1978. This document will be cited as NEOEB (1978).

The remainder of each grab was sieved through a 0.5 mm mesh Nitex screen aboard ship. The material retained on the sieve was placed on $0.5 \mathrm{~mm}$ sieve cloth which was inserted in a muslin bag immersed in a $6 \%$ $\mathrm{MgCl}_{2}$ solution for approximately $30 \mathrm{~min}$. The muslin bag was then placed in $10 \%$ buffered seawater formalin.

\section{Laboratory}

In the laboratory, samples were transferred to $70 \%$ isopropanol prior to processing. Samples were resieved through the original $0.5 \mathrm{~mm}$ Nitex screen cloth and were stained with rose bengal. They were then presorted into major taxa under stereomicroscope. Taxonomic aids included a local reference collection confirmed with specimens from the Smithsonian Institution. Papers cited in the Introduction contained many valuable taxonomic sources.

Pearson's correlation coefficient $(R)$ was computed to determine whether there were any quantitative relationships betweeen mean density per station of dominant species and environmental factors. Significant $R$ values $(0.05)$ indicated that there was a quantitative association (positive or negative) between density of a particular species and depth, for example. In turn, these associations formed the basis of ecological interpretation and discussion. Mean density, depth, temperature, dissolved oxygen, mean phi, microbial biomass (adenosine triphosphate), and bacterial biomass (lipopolysaccharides) were transformed $\log _{e}$ 
$(\mathrm{N}+1)$ and percent sand, percent gravel, percent silt, percent silt-clay, percent carbon, and percent nitrogen were treated to the arcsine transformation. Principal component analysis was used on transformed $\log _{e}(\mathrm{~N}$ +1 ) counts of dominant species. Specific steps in the program are outlined in Nie et al. (1975).

\section{RESULTS}

\section{Top Fifteen Taxa}

During the course of this study, 333 taxa of polychaetes (winter, 263; spring, 264) belonging to 46 families (winter, 30; spring, 33) were identified (Maurer and Leathem, 1980). The top 15 taxa in terms of abundance accounted for a mean of $88 \%$ (winter) and $89.8 \%$ (spring) of the number of polychaetes per station. As a result, the Biological Index Value (BIV) of the top 15 species per station for winter and spring was computed (Maurer and Leathem, 1980). The top 15 taxa for winter were Spiophanes bombyx (Claparede), Exogone hebes (Webster and Benedict), Euclymene collaris (Claparede), Exogone verugera (Claparede), Aricidea catherinae Laubier, Phyllodoce mucosa Oersted, Cirratulidae spp., Parapionosyllis longicirrata (Webster and Benedict), Schistomeringos caeca (Web- ster and Benedict), Spiophanes kroyeri Grube, Sphaerosyllis erinaceus (Claparede), Tharyx sp. B., Goniadella gracilis (Verrill), Sabellidae spp., and Jasmineira filiformis Hartman.

In the spring, the top 15 taxa were $S$. bombyx, E. hebes, E. verugera, Chone infundibuliformis Kroyer, Maldanidae spp., Nephtyidae spp., P. longicirrata, A. catherinae, S. kroyeri, Notomastus latericeus Sars, Cirratulidae spp., Tharyx sp. B., P. mucosa, Euchone incolor Hartman, and $S$. caeca. Among the top 15 species from both seasons, 10 were in common. The same families which dominated the winter were again represented in the spring. In addition, the Nephtyidae and Capitellidae became more important in spring. The significant increase in density of polychaetes from winter to spring was primarily due to $S$. bombyx, C. infundibuliformis, Maldanidae spp., and Nephtyidae spp. Otherwise, seasonal fluctuations among many of the dominant species were slight.

\section{Distribution and Ecological Relationships of Selected Species}

Spiophanes bombyx was sampled widely and occurred in high densities at Stations $1,4,17,18,31,32$, and 39. Densities per station of dominant species are pre-

Table 1. Comparison (significant $R$ values at 0.05 ) of mean density (no. $\mathrm{m}^{-2}$ ) of selected polychaetes from Georges Bank with environmental parameters. Upper line = winter; lower line and underlining $==$ spring

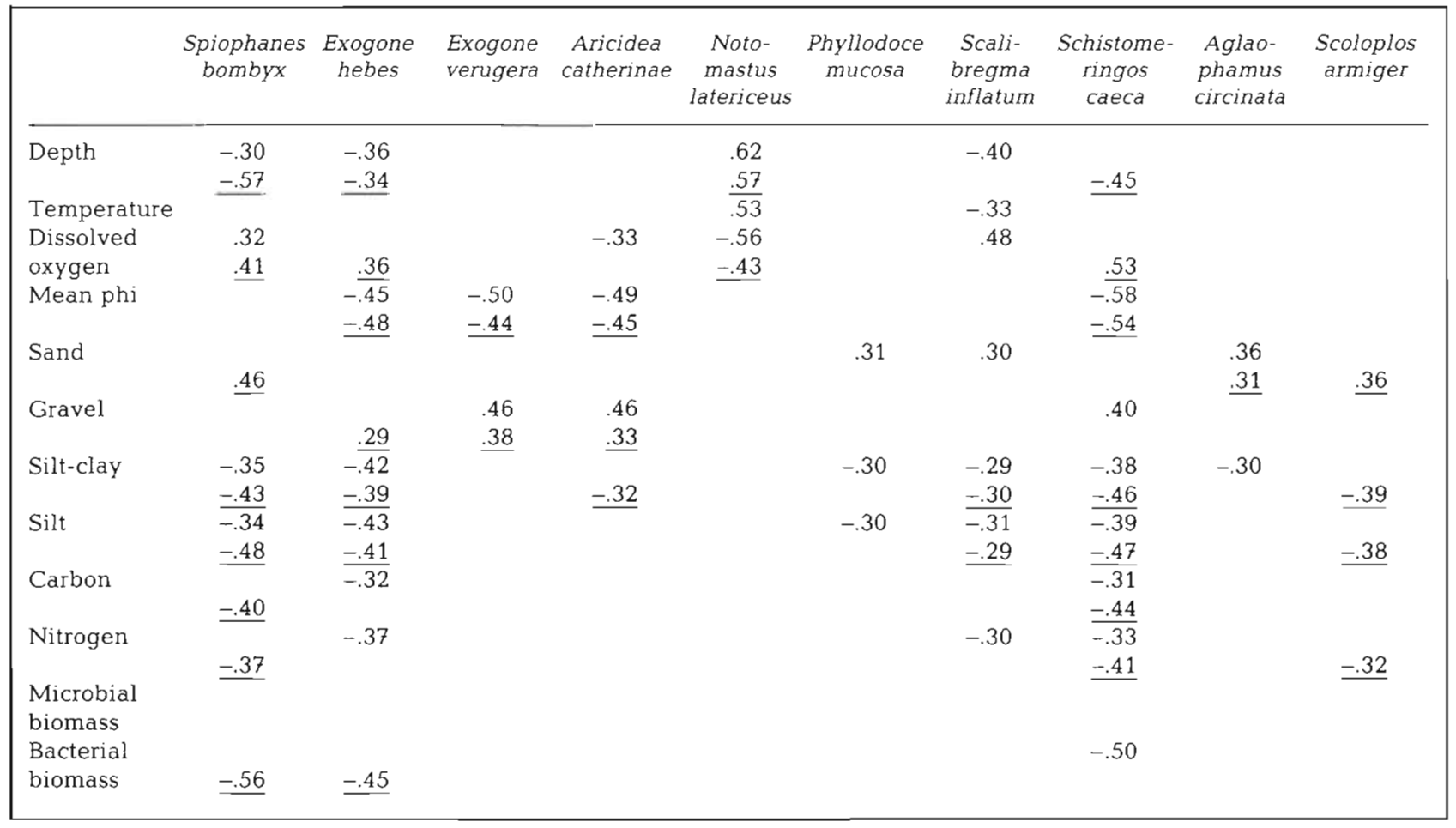


sented in Maurer and Leathem (1980). Mean density of $S$. bombyx decreased in deeper water, lower silt, and silt-clay, and increased with higher oxygen in both seasons (Table 1). In spring, density increased with higher percent sand and lower carbon, nitrogen, and bacterial biomass. Maximum densities occurred in sand between 40 to $50 \mathrm{~m}$ depth. Winter and spring distribution patterns were generally similar. In winter, mean and maximum density was $500 \mathrm{~m}^{-2}$ and 13,138 $\mathrm{m}^{-2}$, respectively; whereas in spring it was $813 \mathrm{~m}^{-2}$ and 7,188 $\mathrm{m}^{-2}$.

Exogone hebes occurred over a broader area than Spiophanes bombyx. Densities were high at Stations 1 . $3,4-5,29-34,37-39$. Mean density decreased in deeper water and fine-grained sediment in both seasons, decreased in sediment with carbon and nitrogen in the winter and bacterial biomass in the spring, and increased with higher oxygen and percent gravel in the spring (Table 1). Highest mean densities occurred in sand and gravel between 20 and $40 \mathrm{~m}$. Its winter and spring geographic distribution was generally similar. In winter, mean and maximum densities were $385 \mathrm{~m}^{-2}$ and $2,480 \mathrm{~m}^{-2}$, respectively; whereas in spring it was $228 \mathrm{~m}^{-2}$ and $3,535 \mathrm{~m}^{-2}$.

The distribution of Exogone verugera was not as broad over the Nantucket Shoals area as that of $E$. hebes. Moreover, E. verugera was less common in the central portion of Georges Bank. Mean density of $E$. verugera increased with percent gravel in both winter and spring. Maximum mean densities were normally recorded in coarse-grained sediment in depths greater than $40 \mathrm{~m}$. E. verugera occurred in slightly higher densities in spring (mean $228 \mathrm{~m}^{-2}$, maximum $3,535 \mathrm{~m}^{-2}$ ) than in winter (mean $211 \mathrm{~m}^{-2}$, maximum $3,943 \mathrm{~m}^{-2}$ ).

Aricidea catherinae occurred broadly throughout the study area and was particularly well represented in stations running down into the Lydonia Canyon area (Stations 13-16, 22-27) and near the Great South Channel (Stations 4-5, 39). Mean density of $A$. catherinae increased with percent gravel in both seasons and decreased with lower oxygen in the winter and higher silt-clay in spring (Table 1). It was generally higher in depths between 20 and $30 \mathrm{~m}$. Densities were higher in winter (mean $161 \mathrm{~m}^{-2}$, maximum $1,861 \mathrm{~m}^{-2}$ ) than in spring (mean $84 \mathrm{~m}^{-2}$, maximum $718 \mathrm{~m}^{-2}$ ).

The distribution of Notomastus latericeus was primarily restricted to the southern (Stations 8, 11-16) and eastern margin of Georges Bank (Stations 32-33) with a few occurrences in the northerm stations (Stations 36, 40). This species was particularly well developed in and around the Lydonia Canyon area (Stations 22-27). $N$. latericeus density increased with depth and lower oxygen in winter and spring increased with higher temperature in winter (Table 1). Highest mean densi- ties were reported from finegrained sediment in depths greater than $40 \mathrm{~m}$. Density was higher in winter (mean $66 \mathrm{~m}^{-2}$, maximum $941 \mathrm{~m}^{-2}$ ) than in spring (mean $50 \mathrm{~m}^{-2}$, maximum $1,480 \mathrm{~m}^{-2}$ ).

Phyllodoce mucosa occurred throughout the study area with several widely separated sites containing high densities (Stations 3, 13-16, 31-32, 36). This species increased with percent sand and decreased with silt and silt-clay in winter. High densities were reported from sand at depths from 40 to $50 \mathrm{~m}$. Density was considerably higher in winter (mean $94 \mathrm{~m}^{-2}$, maximum $2,346 \mathrm{~m}^{-2}$ ) than in spring (mean $23 \mathrm{~m}^{-2}$, maximum $710 \mathrm{~m}^{-2}$ ).

Scalibregma inflatum was mainly restricted to the Nantucket Shoals area (Stations 1-5) and the southern margin of Georges Bank (Stations 8, 24, 26-30). S. inflatum density decreased with higher silt-clay and silt in winter and spring; decreased with depth, higher temperature, and nitrogen in winter; and increased with dissolved oxygen and percent sand in winter (Table 1). Maximum densities were reported from sand in depths of $40 \mathrm{~m}$. Density was higher in spring (mean $37 \mathrm{~m}^{-2}$, maximum $325 \mathrm{~m}^{-2}$ ) than in winter (mean $21 \mathrm{~m}^{-2}$, maximum $198 \mathrm{~m}^{-2}$ ).

Schistomeringos caeca occurred widely throughout the study area with high mean densities near the Great South Channel (Stations 3-5) and eastern Georges Bank (Stations 31-34). S. caeca density decreased with finegrained sediment containing high carbon and nitrogen both in winter and spring, with high bacterial biomass in winter, and with depth in spring; it increased with percent gravel in winter and dissolved oxygen in spring (Table 1). Highest densities occurred in sand and gravel in depths of about $40 \mathrm{~m}$. Densities were higher in winter (mean $64 \mathrm{~m}^{-2}$, maximum $45 \mathrm{~m}^{-2}$ ) than in spring (mean $45 \mathrm{~m}^{-2}$, maximum $658 \mathrm{~m}^{-2}$ ).

Aglaophamus circinata was widely distributed. Its density increased with percent sand in winter and spring and decreased with silt-clay in winter (Table 1). High densities were recorded in sand in depths of $40 \mathrm{~m}$ north of Lydonia Canyon (Stations 11-20). Density was higher in winter (mean $20 \mathrm{~m}^{-2}$, maximum $178.3 \mathrm{~m}^{-2}$ ) than in spring (mean $6.7 \mathrm{~m}^{-2}$, maximum $97.5 \mathrm{~m}^{-2}$ ).

Scoloplos armiger occurred mainly on Georges Bank proper, particularly on the southern (Stations 7-8, 11-27) and eastern (Stations 28-29, 31-34) portions. Its density increased with percent sand and decreased with silt, silt-clay, and nitrogen in spring (Table 1). This species occurred in highest densities in sand between $40-50 \mathrm{~m}$, although it was taken in shallower and deeper water. Mean density was slightly higher in spring (mean $12.5 \mathrm{~m}^{-2}$, maximum $97.5 \mathrm{~m}^{-2}$ ) than in winter (mean $10.6 \mathrm{~m}^{-2}$, maximum $63.3 \mathrm{~m}^{-2}$ ). 


\section{Principal Component Analysis}

Winter

Coordinates (loadings) of the first 3 components accounted for $74 \%$ of the variance (Table 2). Winter stations with high positive loadings on Factor 1 contained high mean densities of $S$. bombyx, E. verugera, A. catherinae, $N$. latericeus, and $S$. caeca. Stations with high positive loadings on Factor 2 contained high mean densities of $S$. armiger, and stations with high positive loadings on Factor 3 contained high mean densities of $S$. inflatum (Table 2).

\section{Spring}

Coordinates of the first 3 components accounted for $71 \%$ of the variance (Table 2). Spring stations with high positive loadings on Factor 1 contained high mean densities of $E$. verugera, $A$. catherinae, $N$. latericeus, S. bombyx, and $S$. caeca. Stations with high positive loadings on Factor 2 contained high mean densities of $S$. armiger, and $E$, hebes. Stations with high positive loadings on Factor 3 contained high mean densities of $P$. mucosa and stations with high negative loadings contained $S$. inflatum (Table 2).

\section{DISCUSSION}

\section{Ecological Relationships of Selected Species}

In an earlier and more geographically restricted study off the Delmarva Peninsula, it was suggested that Spiophanes bombyx and species of syllids, paraonids, and cirratulids should be considered characteristic species along the northeastern continental shelf (Maurer et al., 1976). This study and studies reviewed by Pratt (1973) bear this out.

Spiophanes bombyx was the single most abundant species on Georges Bank for both winter and spring. In

Table 2. Principal component analysis of Georges Bank selected polychaetes, winter and spring

\begin{tabular}{|c|c|c|c|c|c|c|c|c|c|c|}
\hline \multirow[b]{2}{*}{ Variable } & \multicolumn{5}{|c|}{ Winter } & \multicolumn{5}{|c|}{ Spring } \\
\hline & $\begin{array}{l}\text { Eigen } \\
\text { value }\end{array}$ & $\begin{array}{c}\% \text { of } \\
\text { variance }\end{array}$ & $\begin{array}{c}\text { Factor } \\
1\end{array}$ & $\begin{array}{c}\text { Factor } \\
2\end{array}$ & $\begin{array}{c}\text { Factor } \\
3\end{array}$ & $\begin{array}{l}\text { Eigen } \\
\text { value }\end{array}$ & $\begin{array}{c}\% \text { of } \\
\text { variance }\end{array}$ & $\begin{array}{c}\text { Factor } \\
1\end{array}$ & $\begin{array}{c}\text { Factor } \\
2\end{array}$ & $\begin{array}{c}\text { Factor } \\
3\end{array}$ \\
\hline S. bombyx & 4.38 & 43.8 & 0.84 & -0.05 & -0.31 & 3.99 & 39.9 & 0.74 & 0.03 & 0.29 \\
\hline E. hebes & 1.66 & 16.6 & 0.55 & 0.55 & 0.47 & 1.64 & 16.5 & 0.46 & 0.56 & -0.43 \\
\hline E. verugera & 1.36 & 13.6 & 0.84 & -0.16 & 0.21 & 1.45 & 14.6 & 0.88 & 0.00 & -0.27 \\
\hline A. catherinae & 1.14 & 11.4 & 0.76 & 0.38 & -0.35 & 0.72 & 7.2 & 0.80 & -0.11 & 0.34 \\
\hline N. latericeus & 0.52 & 5.3 & 0.72 & -0.27 & 0.43 & 0.69 & 7.0 & 0.75 & -0.22 & -0.28 \\
\hline P. mucosa & 0.29 & 2.9 & 0.46 & 0.13 & -0.44 & 0.48 & 4.8 & 0.47 & 0.16 & 0.66 \\
\hline S. inflatum & 0.22 & 2.2 & 0.51 & -0.14 & 0.61 & 0.44 & 4.4 & 0.44 & 0.14 & -0.60 \\
\hline S. caeca & 0.16 & 1.7 & 0.75 & -0.45 & -0.25 & 0.21 & 2.1 & 0.59 & -0.65 & 0.08 \\
\hline A. circinata & 0.13 & 1.3 & 0.65 & -0.16 & -0.22 & 0.19 & 2.0 & 0.62 & 0.05 & 0.00 \\
\hline S. armiger & 0.10 & 1.1 & 0.27 & 0.90 & 0.00 & 0.14 & 1.5 & 0.20 & 0.88 & 0.28 \\
\hline
\end{tabular}

Table 3. Comparison of estimates of density (mean, maximum, range of no. $\mathrm{m}^{-2}$ ) of selected species of polychaetes from Georges Bank through the Middle Atlantic Bight

\begin{tabular}{|c|c|c|c|c|c|c|c|c|c|c|c|}
\hline \multirow{3}{*}{ Species } & \multicolumn{4}{|c|}{ This study } & \multirow{2}{*}{\multicolumn{4}{|c|}{$\begin{array}{c}\text { Boesch et al. (1976) } \\
\text { Middle Atlantic Bight } \\
\text { Range }\end{array}$}} & \multirow{3}{*}{$\begin{array}{c}\text { Maurer } \\
\text { (unpublished) } \\
\text { off Atlantic } \\
\text { City, NJ } \\
120 \mathrm{~m} \\
\overline{\mathrm{x}}\end{array}$} & \multicolumn{2}{|c|}{$\begin{array}{c}\text { Kinner and } \\
\text { Maurer (1978) } \\
\text { off Delaware }\end{array}$} \\
\hline & & inter & & ring & & & & & & Coastal & Mid-shelf \\
\hline & $\overline{\mathrm{x}}$ & Max. & $\overline{\mathrm{x}}$ & Max. & Fall & Winter & Spring & Summer & & Max. & Max. \\
\hline S. bombyx & 501 & 13,139 & 813 & 7,188 & $130-6,664$ & $17-4,772$ & $310-779$ & $28-2,033$ & 5 & 320 & 2,550 \\
\hline E. hebes & 385 & 2,480 & 364 & 2,408 & $65-418$ & & & & & & 850 \\
\hline E. verugera & 211 & 3,943 & 229 & 3,535 & $142-353$ & & & & 103 & & 1,425 \\
\hline A. catherinae & 161 & 1,862 & 85 & 718 & 42 & $78-353$ & 53 & $17-\quad 177$ & 155 & 240 & 350 \\
\hline N. latericeus & 66 & 942 & 50 & 1,480 & $97-235$ & $42-443$ & $175-207$ & $132-466$ & 103 & & \\
\hline P. mucosa & 95 & 2,347 & 23 & 710 & & & & 62 & 22 & 20 & 25 \\
\hline S. inflatum & 21 & 198 & 37 & 325 & $75-498$ & $192-281$ & & $120-225$ & 89 & & 150 \\
\hline S. caeca & 64 & 537 & 46 & 658 & 55 & & & & 1 & 40 & 50 \\
\hline A. circinata & 20 & 178 & 7 & 98 & 78 & 245 & $62-143$ & $62-$ & 11 & & 825 \\
\hline S. armiger & 11 & 63 & 13 & 98 & & & & & 20 & 20 & 50 \\
\hline
\end{tabular}


addition to being the dominant local species, it occurs widely, frequently, and abundantly throughout the Middle Atlantic Bight (Pratt, 1973; Steimle and Stone, 1973; Maurer et al., 1976). Table 3 contains a list of density estimates (mean, maximum, range) of selected species compared with other studies. Maximum numbers from Georges Bank were higher here than those recorded further south. S. bombyx was a dominant polychaete from central and outer Middle Atlantic shelf stations in Massachusetts Bay, off southwestern Long Island, and in coastal and mid-shelf stations off the Delmarva Peninsula Boesch et al., 1976; (Padan 1977; Steimle and Stone, 1973; Maurer et al., 1976). This species occurs in European waters (Scottish lochs; Plymouth, England; Mediterranean Sea) as well as on the Pacific Coast of the United States (Gibbs, 1969; Bhaud, 1972; Gage, 1972; Richardson et al., 1977) S. bombyx occurred in highest densities in well-sorted sediment $>1.0 \mathrm{~mm}$ (Kinner and Maurer, 1978). Although it seems to be characteristic of sandy shelf $(30-60 \mathrm{~m})$ habitats, it has been reported as the second most abundant spionid in the New York Bight (Pearce, 1972). This species attained densities of over $2,000 \mathrm{~m}^{-2}$ in organically enriched sediments. S. bombyx also occurs as an intertidal species in Barnstable Harbor, Massachusetts (Whitlatch, 1977) and Georgetown, South Carolina (Holland and Dean, 1977). Whitlatch (1977) listed May through June and June through August as the periods of peak abundance and reproductive activity, respectively. Our peak estimate (Table 3) is consistent with his peak abundance. Boesch (1976) cited some long-term studies in the German Bight which showed that population eruptions of $S$. bombyx were related to the elimination of the bivalve Tellina fabula due to severe winters. Off the Columbia River, Richardson et al. (1977) reported that the instability of several species, including $S$. bombyx, contributed to yearly variations in community structure.

The two syllids Exogone hebes and E. verugera were the second and third most abundant species from Georges Bank. Both were identified by Boesch et al. (1976) as important species from central and outer shelf stations and by Maurer et al. (1976) from the mid-shelf off the Delmarva Peninsula. Both species increased in coarser sediment (Table 1). In shallow water in Plymouth Sound, England, Gibbs (1969) reported densities of E. hebes ranging from 4,574 to $11,500 \mathrm{~m}^{-2}$ in fine sand. E. verugera was the second most abundant species in a bay in Baja, California (Reish, 1963). Its maximum density reported there was $5,000 \mathrm{~m}^{-2}$ with a mean of $205 \mathrm{~mm}^{-2}$ in silt and $104 \mathrm{~m}^{-2}$ in fine sand. Blake and Dean (1973) collected E. verugera with eggs in a brood sac attached to the abdomen, while Maurer et al. (1976) noted that specimens collected in
November commonly contained sexual epitokes with long swimming setae.

Among the Paraonidae, which was a very diverse family on Georges Bank (Maurer and Leathem, 1980), Aricidea catherinae was the most abundant species. At the recommendation of Dr. M. Pettibone (Kinner and Maurer, 1978), Aricidea jeffreysii and $A$. cerruti (not Laubier) have been referred to $A$. catherinae. Accordingly, we have included available ecological literature information on $A$. jeffreysii and $A$. Cerruti (not Laubier) with $A$. catherinae. A. jeffreysii occurred in Massachusetts Bay in cobbles $\left(100 \mathrm{~m}^{-2}\right)$ and mud $\left(123 \mathrm{~m}^{-2}\right)$ (Padan, 1977). This species was cited from the Chesapeake Bay area and off North Carolina by Kinner and Maurer (1978). It is widely distributed throughout the upper reaches of the Hudson Canyon (Pearce, 1972). According to Pearce, there is apparently intense competition among members of the Cossuridae, Paronidae, and Spionidae. Gage (1972) reported a density for $A$. jeffreysii of $916 \mathrm{~m}^{-2}$ in soft mud from a Scottish loch. This sediment distribution contrasts with the pattern recognized for Georges Bank (Table 1). In Delaware Bay, A. Catherinae was negatively associated with an increase in median sediment size (Kinner and Maurer, 1978) The period of peak abundance and reproductive activity of $A$. catherinae (A. jeffreysii) in Barnstable Harbor was April-May and July, respectively (Whitlatch, 1974).

Notomastus latericeus occurs throughout the Middle Atlantic Bight and was recorded in high densities from the shelf south of Georges Bank. This species was taken uniformly throughout the year off the New Jersey coast. At outer shelf swale and shelf break stations, it was among the dominant species (Boesch et al., 1976). This deeper depth distribution was similar to the one we reported.

Phyllodoce mucosa has been recognized throughout the Middle Atlantic Bight (Table 2). It was among the top 20 species from a shallow water benthic community in Nova Scotia where a mean density of $182 \mathrm{~m}^{-2}$ was recorded (Levings, 1975). In Massachusetts Bay, this species was collected from a variety of sediment types but was most abundant (100-120 $\mathrm{m}^{-2}$ ) in cobbles (Padan, 1977). In samples collected from the Nova Scotia shelf to Cape Hatteras, Kinner (1978) described $P$. mucosa among the top (frequency) 15 errantiate polychaetes. The greatest number of occurrences $(89 \%)$ were recorded between 40 and $86 \mathrm{~m}$. Based on polynomial regression analysis, median phi, depth, silt-clay, and major sediment mode accounted for $71.7 \%$ of the variance in distribution (Kinner, 1978).

Scalibregma inflatum occurs widely throughout the Middle Atlantic Bight, but rarely in the densities recorded for $S$, bombyx or the syllids. $S$. inflatum was among numerical dominants at outer shelf stations 
(Boesch et al., 1976). This distribution contrasts with the increase in density with decreasing depth and increased percent of sand recorded by us (Table1). $S$. inflatum was positively correlated with sand and gravel in the Beaufort Sea (Bilyard and Carey, 1979).

Aithough Schistomeringos caeca occurs throughout the Middle Atlantic Bight area, its apparent relative omission from the literature may be in part attributed to changes in taxonomic usage. Boesch et al. (1976) recognized it among one of their species groups. This species increased with decreasing depth and increasing sediment size (Table 1).

Aglaophamus circinata was the dominant species among the diverse family Nephtyidae (Maurer and Leathem, 1980). It was recorded in high densities south of Georges Bank. Kinner (1978) cited A. circinata among the top 15 errantiate polychaetes from the Nova
Scotia shelf to Cape Hatteras. The greatest number of occurrences $(86 \%)$ was between 40 and $100 \mathrm{~m}$ and fine to medium sands $(85 \%)$. Based on polynomial regression analyses, sorting, silt-clay, and depth accounted for $30.4 \%$ of its variance (Kinner, 1978).

In addition to having a widespread distribution throughout the Middle Atlantic Bigth, Scoloplos armiger has been recognized widely throughout European waters (Plymouth Sound: Gibbs, 1969; Scottish loch: Gage, 1972; Mediterranean Sea: Bhaud, 1972). Gibbs (1968) reviewed the ecology of $S$. armiger and stated that this species tolerates a wide variety of sediment grades, but is generally most abundant in muddy sand where the proportion of silt is fairly high. According to our analyses, $S$. armiger decreased with increasing silt and silt-clay; and Hughes et al. (1972) reported $S$. armiger abundant from coarse sediment in Nova Sco-

Table 4. Comparison of total number of polychaete species and number of species per dominant polychaete families from selected shelf studies

\begin{tabular}{|c|c|c|c|c|c|c|c|c|c|c|c|}
\hline & 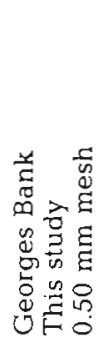 & 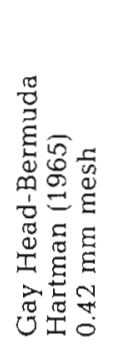 & 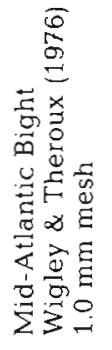 & 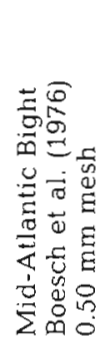 & 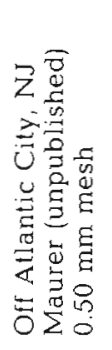 & 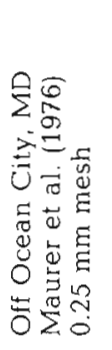 & 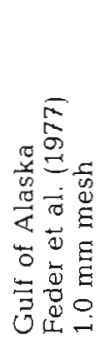 & 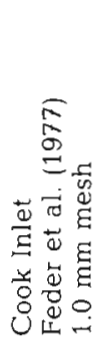 & 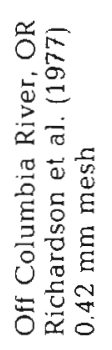 & 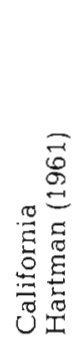 & 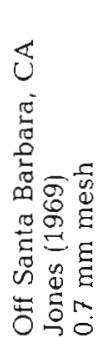 \\
\hline Total No. of species & 333 & 266 & 91 & $=250$ & 122 & 70 & 132 & 93 & 216 & 650 & $523^{\circ}$ \\
\hline \multicolumn{12}{|c|}{ No. of species per family: } \\
\hline Ampharetidae & 17 & 13 & 4 & 11 & 7 & & 11 & & 8 & 22 & \\
\hline Capitellidae & & & & 7 & & & & & 13 & 24 & \\
\hline Cirratulidae & 16 & 9 & 4 & & 8 & 5 & & & 8 & 23 & $\mathrm{x}$ \\
\hline Cossuridae & & & & & & & & & & & $\mathrm{x}$ \\
\hline Eunicidae & & & & 8 & & & & & & & \\
\hline Flabelligeridae & & 8 & & 7 & & & 6 & & & 14 & \\
\hline Glyceridae & & & 5 & & & & & & & 13 & $\mathrm{x}$ \\
\hline Lumbrineridae & 11 & 7 & 4 & 11 & 6 & 5 & & 5 & 9 & 22 & $\mathrm{x}$ \\
\hline Maldanidae & 15 & 24 & & 11 & 4 & 4 & 15 & 8 & 14 & & \\
\hline Nephtyidae & 10 & 7 & 5 & 6 & 4 & 4 & 8 & 8 & 10 & 14 & $\mathrm{x}$ \\
\hline Nereidae & 7 & 9 & & & & & & & & 28 & \\
\hline Onuphidae & 5 & & 7 & 12 & 4 & & & & & 22 & \\
\hline Ophelidae & 6 & 8 & 4 & & & & & & & 16 & \\
\hline Orbiniidae & 9 & 7 & & 10 & & & & & & 14 & $\mathrm{x}$ \\
\hline Paraonidae & 21 & 15 & & 16 & 13 & 5 & 6 & 5 & 8 & & $\mathrm{x}$ \\
\hline Pectinariidae & & & & & & & & & & & $\mathrm{x}$ \\
\hline Phyllodocidae & 12 & 9 & 5 & 15 & & 5 & 8 & & 22 & 35 & \\
\hline Polynoidae & 11 & & & 6 & & & 11 & & 11 & 43 & \\
\hline Sabellidae & 12 & 7 & 4 & 9 & & & 10 & & & 27 & \\
\hline Serpulidae & & & & & & & & & & 24 & \\
\hline Sigalionidae & & & 4 & & & & & & & 11 & $\mathrm{x}$ \\
\hline Spionidae & 25 & 12 & 7 & 18 & 9 & 3 & 9 & 7 & 14 & 45 & $\mathrm{x}$ \\
\hline Sternaspidae & & & & & & & & & & & $\mathrm{x}$ \\
\hline Syllidae & 29 & 13 & & 26 & 8 & 9 & 9 & 5 & 9 & 39 & \\
\hline Terebellidae & 26 & & & 9 & 7 & & & & & 38 & \\
\hline
\end{tabular}


tia. Luksenas (1969) stated that the $S$. armiger biocoenosis was the deepest living biocoenosis in the southern part of the Baltic Sea, thriving at depths of 84 to $123 \mathrm{~m}$. S. armiger may comprise $56 \%$ of the total biomass and occurs in densities of $220 \mathrm{~mm}^{-2}$ and biomass of $2.3 \mathrm{~g} \mathrm{~m}^{-2}$. In some cases, it is the only species in the Baltic biocoenosis because of widespread oxygen deficiency.

\section{Quantitative Composition of Polychaetes on Continental Shelf Areas}

In this study, winter populations of polychaetes comprised approximately $54 \%$ of the number of all infaunal species and $53 \%$ of the density. Sixteen families were recognized as relatively important ones. To offer some impression of the importance of specific families of polychaetes to benthic biota of continental shelf areas in cooler North American waters, we compared our data with other studies (Table 4).

In samples from the Gay Head-Bermuda transect, 266 species of polychaetes belonging to 50 families were identified by Hartman (1965). In a study ranging from southern New England to the Chesapeake Bight (Wigley and Theroux, 1976), polychaetes represented $21 \%$ of the density of the number of species and $21 \%$ of the density of the macrofauna. Polychaetous annelids numerically dominated collections at most stations in the Middle Atlantic Bight, usually comprising 40 to $60 \%$ and occasionally up to $90 \%$ of the individuals (Boesch et al., 1976). Over 250 polychaetes were identified, and this number is expected to increase as more difficult taxa are treated by specialists. Off Atlantic City, New Jersey, in $120 \mathrm{~m}$ of water, polychaetes accounted for $54 \%$ of the number of species (225) and 70 to $80 \%$ of the density (122) (Maurer, unpublished). Off Ocean City, Maryland, 70 out of 149 species or $47 \%$ of the faund were polychaetes and 40 out of 149 or $27 \%$ were crustaceans (Maurer et al., 1976).

On other shelf studies similar patterns emerge. In the Gulf of Alaska, 457 infaunal species were identified (Feder et al., 1977). Polychaetous annelids comprised the most important group with 132 species or $29 \%, 69$ species of molluscs or $15 \%$, and 66 species of crustaceans or $14 \%$. In Cook Inlet, 211 species included 93 species of polychaetes (44\%), 64 species of molluscs $(30 \%), 33$ species of crustaceans (16\%). In the Bering Sea, 643 species were isolated from 59 stations (Feder et al., 1977). Annelids contained 180 species (28\%), arthropods 120 species (19\%), and molluscs 109 species $(17 \%)$. On the West Beaufort Shelf, annelids comprised 31.7 to $86.6 \%$ ot the total numbers of infauna (Carey et al., 1974).
Off the mouth of the Columbia River, Richardson et al. (1977) reported 216 species (60\%) of polychaetes from 357 species of benthic invertebrates, and 523 types of polychaetes $(36 \%$ ) were identified from a total of 1,473 invertebrate macrofauna on the Santa Barbara, California shelf (Jones, 1969). Hartman (1961) listed 650 polychaetes in her comprehensive study of California waters.

Among 11 representative studies (Table 4), the total number of polychaete species ranged from 70 to 650 . Out of 81 polychaete families recognized by Fauchald (1977), 25 were recognized as being important in one study or another. Among the 11 studies, Nephtyidae and Spionidae were deemed important in all studies; Lumbrineridae in 10; Paraonidae and Syllidae in 9; Ampharetidae, Cirratulidae, Maldanidae, and Phyllodocidae in 8 (Table 4). On the other hand, the Cossuridae, Eunicidae, Pectinariidae, Serpulidae, and Sternaspidae were cited as important families in only 1 study. Moreover, some of the families recognized as important in 3 to 6 studies contained substantial numbers of species (Capitellidae, Nereidae, Onuphidae, Orbiniidae, Polynoidae, and Terebellidae).

It appears that about 15 families of polychaetes are mainly characteristic of shelf waters ranging from California to Alaska and Chesapeake Bay to Georges Bank. Future studies should emphasize the abovementioned families as an important prerequisite in understanding benthic communities (Knox, 1977; Reish, 1979). Although the biology of all shelf polychaete species should be a long-term research goal, recognition of dominant taxa per particular shelf area and the elucidation of their respective biology should be a short-term goal in view of their value in basic and applied ecology.

Acknowledgements. This work was initially funded through Contract No. AA550-CT6-51 of the Bureau of Land Management and completed through funds provided by the College of Marine Studies, University of Delaware. We would like to thank Drs Roland Wigley, Allan Michael, Kristian Fauchald, Don Boesch, and Mr. Kenneth Berger who critically read an earlier draft.

\section{LITERATURE CITED}

Banse, K., Hobson, K. D. (1974). Benthic errantiate polychaetes of British Columbia and Washington. Bull. Fish. Res. Bd Can. 185: 1-111

Bhaud, M. (1972). Quelques donnees sue le determinisme ecologique de la reproduction des Annelides Polychetes. Mar. Biol. 17: 115-136

Bilyard, G. R., Carey, A. G., Jr. (1979). Distributional patterns of Western Beaufort Sea polychaetous annelids. Mar. Biol. 54: $329-339$

Blake, J. A. (1969). Reproduction and larval development of Polydora from northern New England (Polychaeta: Spionidae). Ophelia $7: 1-63$ 
Blake, J. A. (1971). Revision of the genus Polydora from the East Coast of North America (Polychaeta: Spionidae). Smithson. Cont. Zool 75: 1-32

Blake, J. A., Dean, D. (1973). Polychaetous annelids collected by the R/V Hero from Baffin Islands, Davis Strait, and West Greenland in 1968. Bull. South. Calif. Acad. Sci. 72: 31-39

Boesch, D. F. (1976). The dynamics of estuarine benthic communities. In: Wiley, D. J. (ed.) Estuarine processes, Vol. 1. Academic Press, New York, pp. 177-196

Boesch, D., Kraeuter, J. N., Serafy, D. K. (1976). Draft benthic ecological studies: megabenthos and macrobenthos. In: Middle Atlantic outer continental shelf environmental studies. Report to the Bureau of Land Management, Gloucester Point, Virginia. Chapter 6, pp. 1-111

Carey, A. G., Ruff, R. E., Castillo, J. G., Dickinson, J. J. (1974). Benthic ecology of the Western Beaufort Sea continental margin: preliminary results. In: Reed, J. C., Sater, J. E. (eds) The coast and shelf of the Beaufort Sea. The Arctic Institute of North America, Calgary, Alberta, Canada, pp. $665-680$

Creaser, E. P. (1973). Reproduction of the bloodworm (Glycera dibranchiata) in the Sheepscot Estuary, Maine. J. Fish. Res. Bd Can. 30; 161-166

Day, J. H. (1967a). A monograph on the Polychaeta of Southern Africa. Part 1. Errantia. Publ. Br. Mus. Nat. Hist. 656: $1-458$

Day, J. H. (1967b). A monograph on the Polychaeta of Southern Africa. Part 2. Sedentaria. Publ. Br. Mus. Nat. Hist. 656: $1-878$

Day, J. H. (1973). New Polychaeta from Beaufort, with a key to all species recorded from North Carolina. NOAA Tech. Rep. NMFS CIRC-373: $140 \mathrm{pp}$

Dean, D. (1965). On the reproduction and larval development of Streblospio benedicti Webster. Biol. Bull., mar. biol. Lab., Woods Hole 128: 67-76

Dean, D. (1978a). Migration of the sandworm Nereis virens during winter nights. Mar. Biol. 45: 165-173

Dean, D. (1978b). The swimming of bloodworms (Glycera spp.) at night, with comments on other species. Mar. Biol. 48: $99-104$

Fauchald, K. (1977). The polychaete worms definitions and keys to the orders, families, and genera. Allan Hancock Foundation, University of Southern California. Sci. Ser. 28: $1-88$

Fauvel, P. (1923). Faune de France, Polychetes errantes, P. Lechevalier, Paris, 5: 1-488

Fauvel, P. (1927). Faune de France, Polychetes sedentaires, P. Lechevalier, Paris, 16: 1-494

Feder, H. M., Haflinger, K., Hilsinger, J., Hoberg, M., Jewett, S., Matheke, G., Mueller, G. (1977). The distribution, abundance, diversity, and biology of benthic organisms in the Gulf of Alaska and the Bering Sea. In: Environmental assessment of the Alaskan Continental Shelf, Vol. VIII, Receptors - fish, littoral, benthos. National Oceanographic and Atmosphering Administration, Environ. Res. Lab., Boulder, Colorado, pp. 366-712

Foster, N. M. (1971). Spionidae (Polychaeta) of the Gulf of Mexico and the Caribbean Sea. Studies on the fauna of Curacao and other Caribbean Islands. Uitg. Natuurw. Studkring Suriname 63, Vol. 36 (129): 1-183

Gage, J. (1972). Community structure of the benthos in Scottish sea lochs. I. Introduction and species diversity. Mar. Biol. 14: 281-297

Gardner, S. L. (1975). Errant polychaete annelids from North Carolina. J. Elisha Mitchell scient. Soc. 91: 77-220

Gibbs, P. E. (1968). Observations on the population of Scolo- plos armiger at Whitstable. J. mar. biol. Ass. U.K. 48: 225-254

Gibbs, P. E. (1969). A quantitative study of the polychaete fauna of certain fine deposits in Plymouth Sound. J. mar. biol. Ass. U. K. 49: 311-326

Hartman, O. (1961). Polychaetous annelids from California. Allan Hancock Paci. Exped. 25: 1-226

Hartman, O. (1965). Deep-water benthic polychaetous annelids off New England to Bermuda and other North Atlantic areas. Occ. Pap. Allan Hancock Fdn 28: 1-378

Hartman, O., Fauchald, K. (1971). Deep-water benthic polychaetous annelids off New England to Bermuda and other North Atlantic areas. Part II. Allan Hancock Monogr. mar. Biol, 6: 1-327

Hartmann-Schröder, G. (1971). Die Tierwelt Deutschlands, 58. Teil: Annelida, Borstenwürmer, Polychaeta, VEB Gustav Fischer Verlag, Jena

Hughes, R. N., Peer, D. L., Mann, K. H. (1972). Use of multivariate analysis to identify functional components of the benthos in St.Margaret's Bay, Nova Scotia. Limnol. Oceanogr. 17: 111-121

Jones, G. F. (1969). The benthic macrofauna of the mainland shelf off Southern California. Allan Hancock Monogr. mar. Biol. 4: 1-219

Kinner, P. C. (1978). The distribution and ecology of errantiate polychaetes on the continental shelf from Cape Cod to Cape Hatteras. M. Sc. thesis, College of Marine Studies, University of Delaware, Lewes, Delaware

Kinner, P. C., Maurer, D. (1978). Polychaetous annelids of the Delaware Bay region. Fishery Bull. 76: 209-224

Knox, G. A. (1977). The role of polychaetes in benthic soft bottom communities. In: Reish, D. J., Fauchald, K. (eds) Essays on polychaetous annelids. In Memory of Dr. Olga Hartman. Allan Hancock Foundation, University of Southern California, Los Angeles, California

Levings, C. D. (1975). Analyses of temporal variation in the structure of a shallow-water benthic community in Nova Scotia. Int. Revue ges. Hydrobiol. 60; 449-470

Luksenas, J. K. (1969). Biocoenoses and trophic groups of bottom invertebrates in the southern part of the Baltic Sea. Oceanology 9: 866-874

Mangum, D. P. (1964). Studies on speciation in maldanid polychaetes of the North American Atlantic Coast. II. Distribution and competitive interaction of five sympatric species. Limnol. Oceanogr. 9: 12-26

Maurer, D., Kinner, P., Leathem, W., Watling, L. (1976). Benthic faunal assemblages off the Delmarva Peninsula. Estuar. \& Coast. Mar. Sci. 4: 163-177

Maurer, D. L., Leathem, W. (1980). Ecological Distribution of Polychaetous Annelids of Georges Bank, Technical Report, College of Marine Studies, University of Delaware

New England OCS Environmental Benchmark (1978). Draft final report to Bureau of Land Management, Volumes I-V, Energy Resources Co., Inc., Cambridge, Massachusetts

Nie, N. H., Hull, C. H., Jenkins, J. G., Steinbrenner, K., Bent, D. H. (1975). Statistical package for the social sciences, McGraw-Hill, New York

Padan, J. W. (Ed.) (1977). New England offshore mining environmental study (Project NOMES). National Oceanographic and Atmospheric Administration Special Report, Environ. Res. Lab., Boulder, Colorado

Pearce, J. (1972). The effects of waste disposal in the New York Bight, Final Report, Section 2: Benthic studies. Rep. to Coastal Engineering Research Center, U.S. Army Corps of Engineers from the National Marine Fisheries Service, Sandy Hook Laboratory

Peer, D. L. (1970). Relation between biomass, productivity, 
and loss to predators in a population of a marine benthic polychaete, Pectinaria hyperborea. J. Fish. Res. Bd Can. 27: $2143-2153$

Pettibone, M. H. (1962). New species of polychaete worms (Spionidae: Spiophanes) from the East and West Coast of North America. Proc. biol. Soc. Wash. 75:77-78

Pettibone, M. H. (1963a). Marine polychaete worms of the New England region. 1 Aphroditidae through Trochochaetidae. Bull. U.S. natn. Mus. 227: 1-356

Pettibone, M. H. (1963b). Revision of some genera of polychaete worms of the Family Spionidae, including the description of a new species of Scolelepis. Proc. biol. Soc. Wash. 76: 89-104

Pettibone, M. H. (1965). Two new species of Aricidea (Polychaeta, Paraonidae) from Virginia and Florida, and redescription of Aricidea fragilis Webster. Proc. biol. Soc. Wash. 78: 127-140

Pettibone, M. H. (1966). Revision of the Pilargidae (Annelida: Polychaeta), including descriptions of new species, and redescription of the pelagic Podarmus ploa Chamberlin (Polynoidae). Proc. U.S. natn. Mus. 3525 (118): 155-208

Pettibone, M. H. (1969). Revision of the Aphroditoid polychaetes of the Family Eulepthidae Chamberlin (= Eulepidinae Darboux ${ }_{i}=$ Pareulepidae Hartman). Smithson. Cont. Zool. 41: 1-44

Pettibone, M. H. (1970a). Two new genera of Sigalionidae (Polychaeta). Proc. Biol. Soc. Wash. 83: 365-386

Pettibone, M. H. (1970b). Revision of some species referred to Leanira Kinberg (Polychaeta: Sigalionidae). Smithson. Cont. Zool. 53: 1-25

Pettibone, M. H. (1971). Revision of some species referred to Leptonereis, Nicon, and Laeonereis (Polychaeta: Nereididae). Smithson. Cont. Zool. 104: 1-53

Pettibone, M. H. (1975). Review of the genus Hermenia with a description of a new species (Polychaeta: Polynoidae: Lepidonotinae). Proc. Biol. Soc. Wash. 88 (22): 233-248

Pettibone, M. H. (1976). Contribution to the polychaete family Trochochaetidae Pettibone. Smithson. Contr. Zool. 230: $1-21$

Pettibone, M. H. (1977). The synonymy and distribution of the estuarine Hypaniola florida (Hartman) from the East Coast of the United States (Polychaeta: Ampharetidae: Lepidonotinae). Proc. biol. Soc. Wash. 90 (2): 205-208

Pratt, S. D. (1973). Benthic fauna. In: Saila, S. B. (ed.) Coastal offshore environmental inventory, Cape Hatteras to Nantucket Shoals. University of Rhode Island, Marine Publication Series No. 2, Chapter 5: 1-70

Reish, D. J. (1963). A quantitative study of the benthic polychaetous annelids of Bahia de San Quitin, Baja, California. Pacif. Nat. 3 (14): 399-436

Reish, D. J. (1979). Bristle worms (Annelida: Polychaeta). In: Hart, C. W., Fuller, S. L. H. (eds) Pollution ecology of estuarine invertebrates. Academic Press, New York, pp. $77-125$

Richards, S. W., Riley, G. A. (1967). Benthic epifauna of Long Island Sound. Bull. Bingham oceanogr. Coll. 19: 89-135

Richardson, M. D., Carey, A. G., Colgate, W. A. (1977). Aquatic Disposal Field Investigations Columbia River Disposal Site, Oregon. Appendix C: The effects of dredged material disposal on benthic assemblages. U. S. Army Corps of Engineers Dredged Material Research Program, Vicksburg, Mississippi. Technical Report D-77-30, 411 pp

Sanders, H. L. (1956). Oceanography of Long Island Sound. X. The biology of marine bottom communities. Bull. Bingham oceanogr. Coll. 15: 345-407

Simon, J. L. (1967). Reproduction and larval development of Spio setosa (Spionidae: Polychaeta). Bull. mar. Sci. 17: 398-431

Steimle, F. W., Stone, R. B. (1973). Abundance and distribution of inshore benthic fauna off southwestern Long Island, New York. Technical Report National Marine Fisheries Service, SSRF-673: 1-50

TRIGOM-PARC (1974). A socio-economic and environmental inventory of the North Atlantic region, Vol. 1, Book 3, 1: 198. Report to the Bureau of Land Management, South Portland, Main

Whitlach, R. B. (1974). Food resource partitioning in the deposit-feeding polychaete Pectinaria gouldii. Biol. Bull. mar. biol. Lab., Woods Hole 147: 227-235

Whitlach, R. B. (1977). Seasonal changes in the community structure of the macrobenthos inhabiting the intertidal sand and mud flats of Barnstable Harbor, Massachusetts. Biol. Bull. mar. biol. Lab., Woods Hole 152: 275-294

Wigley, R. L., Theroux, R. B. (1976). Macrobenthic invertebrate fauna of the middle Atlantic Bight Region: Part II. Faunal Composition and Quantitative Distribution, National Marine Fisheries Center, Woods Hole, Massachusetts 